International Journal of Biology, Pharmacy

and Allied Seiences (IJBPAS)

'A Bridge Betuen Caboratory and Qnendo'

Www.ijbpas.com

\title{
LEADERSHIP AND MANAGEMENT COMPETENCIES FOR HEALTH CARE ORGANIZATIONS
}

\section{NACHIKETA MISHRA}

Symbiosis Institute of Business Management Pune, Symbiosis International (Deemed University), Pune, India

*Corresponding Author: E Mail: nachiketa.mishra.mbals22@associates.sibmpune.edu.in

Received $19^{\text {th }}$ May 2021; Revised $4^{\text {th }}$ June 2021; Accepted $9^{\text {th }}$ July 2021; Available online $25^{\text {th }}$ Sept. 2021

https://doi.org/10.31032/IJBPAS/2021/10.9.1003

\begin{abstract}
The health care sector is characterised by constant reforms aimed at the efficient delivery of safe, effective, and high-quality care. Effective leadership is required to lead and drive changes at all levels of the health system to actualise the goals of the ongoing reforms in health care organisations. Leadership in the health care sector is spread across management and clinical workforces, creating peculiar challenges. The chapter examines the concept of leadership in the health care sector within the context of the recent drive by health care organisations to identify essential competencies and training required by health management and leadership workforces for effective performance in roles. It concludes that further research is needed to build the evidence on the relationships between targeted training and professional development interventions, individual competence of leaders from health management and clinical backgrounds and organisational performance.
\end{abstract}

Keywords: health leadership, health management, competencies, training, professional

\section{development}

\section{INTRODUCTION}

The health care environment is complex and its unique characteristics as well as those dynamic; it experiences problems peculiar to besetting organisations in other sectors [1-3]. 
Such problems include internal pressures arising from increased demands for transparency and accountability, increasing influence of various stakeholders, such as political and social groups, who have vested interests in the sector, and shortages of health care professionals due to the effect of ageing workforces [4-6]. Factors outside the health care environment, such as changing population demographics, economic factors, globalisation, government policies, and advancement in medical and information technologies, also exert profound influences on the health sector [7-9]. Thus, the health care sector undergoes constant reforms arising from the interplay of factors both within and outside its control. Such reforms are necessary to meet the expectations of the population and ensure the delivery of safe, effective, and high quality-healthcare.

Effective leadership has been recognised as crucial in shaping organisational culture and driving the implementation of reforms in health care sector. This is evident in the growing interests in the concepts of health management and leadership, especially since the turn of the century, as reflected in the prevalence of studies on health management and leadership across different countries. Countries include Australia [3, 10, 11], Canada [12, 13], Ireland [14], Latin America
[15], New Zealand [16], South Africa [1719], and the United States of America [2023]. Current interests in health management and leadership are, however, geared towards identification and assessment of essential competencies (that is knowledge, skills, and attitudes) required by health managers and leaders for effective performance in roles. Identification of such competencies is central to initiating appropriate training or professional development to enhance individual competence and improve organisational performance [21].

The purpose of this chapter is to examine the concept of 'leadership' in relation to the health care sector. This is achieved through a review of key studies on health management and leadership to provide contextual understanding of the concept and identify key areas of focus by health care organisations and researchers related to leadership in the health care sector.

\section{Overview of the concept of leadership} in the health care sector

In the health care sector, the term 'leadership' is closely associated, and often used inter- changeably, with 'management'. Thus, this section presents an overview of the concept of leadership in the health care sector, drawing upon both management and leadership asboth terms are seen as being 
relevant to health care services.

In a general sense, management entails planning, organising, control, budgeting, implementation, and evaluation; it ensures efficient utilisation of resources to achieve organisational goals [24]. The concept of management has been described as' unique' in the sense that it has no universal application but rather is dictated by context, that is the policies, structures, and cultural values in which it is practised [25]. There are different schools of thought in management; one such school is the 'traditional' or bureaucratic (scientific) approach to management which emphasises a clear management structure, based on hierarchical chains of command involving workers' control and accountability for performance [26]. A competing school is the human relations approach to management which focuses on involvement of workers in the design of their work (participation, selfgovernance), motivating workers, satisfying their needs, promoting quality of life at work and managing conflict [27]. Numerous other theories of general management have followed, including institutional theory, open system and resource dependence theories, strategic management perspective, and organisational ecology [27]. These theories are beyond the scope of this chapter.
Leadership, on the other hand, revolves around vision, ideas, direction, and inspiration; it establishes direction [28, 29] and motivates others $[30,31]$ to achieve organisational goals rather than a focus on day-to-day implementation of those goals [24]. According to (Bennis and Nanus [32] p. 21), "managers are people who do things right and leaders are people who do the right thing. The difference may be summarised as activities of vision and judgment (effectiveness) versus activities of mastering routines (efficiency)". Regardless of the differences between management and leadership in terms of roles and functions, both are recognised as important to the attainment of organisational goals and objectives [24].

Although management and leadership may represent two distinct disciplinary and practice areas, distinguishing between the two concepts in practice may be difficult [24]. In certain instances, management functions can provide leadership while leadership activities can contribute to managing [24]. Additionally, managers and leaders are expected to function effectively in different situations, not limited by their traditional roles, reflecting the view that they (managers and leaders) are expected to be all things to all people [33]. This view is 
consistent with that of Bass and Avolio [34] who opined that effective leadership is a reflection of a noptimalmix of different styles, including management and leadership practices. Furthermore, the concept of 'distributed leadership' [35], which suggests one does not need to have a formal position of managerial authority to be a 'leader', further renders the debates on management/ leadership dichotomy as less important. Thus, while the distinction between management and leadership arises from the differences in roles and functions, the reality is that a role is often unconsciously chosen and not outlined explicitly in the organisation [36]. A role appears and changes as a result of gaps that need to be filled in the managerial jobs.

Arising from changes in the social context of health care, the dichotomy between management and leadership in the sector is increasingly narrowing [37]. Thus, managers (generalist trained managers, professional health service managers) fill management roles, perform management functions and provide leadership. On the other hand, clinicians (including doctors and nurses) and other professionals with no background in management may move into management roles and provide leadership. One change which has significantly affected the social context of health care is the increasing involvement of clinicians in the planning, management, and organisation of care in line with the concept of clinical leadership. Clinical leadership is provided by clinicians in clinical settings to ensure safe, effective, and high-quality care $[38,39]$. Such roles are usually performed in collaboration with nonclinical management or leadership roles and functions. Thus, in the health care sector, a 'managerialism' model, dominated by generalist trained managers, is being replaced by a unified (collective) leader- ship structure for the effective running of health care services. Such an approach to management is somewhat similar to the concept of 'distributed' or 'shared' leadership (see below), where different actors engage in tasks that are 'stretched' or distributed across the organisation [40].

There are many leadership theories which underlie management and leadership practices; prominent among them is contingency theory. Contingency (or situational) theory emerged in the early 1960 s due to inability of previous theories to explain different aspects of leader behaviour [36]. Contingency theory is based on the premise that the behaviour exhibited by a leader varies, depending on the prevailing circumstance or situation [41-44]. According 
to Smirich and Morgan [45], leadership is a product of interaction between the situation, the leader, and the followers. Other theories which have their roots in contingency theory include transactional and transformational leadership theories, which were introduced by Burns in 1978 [36]. Transactional leaders are associated with contingency rewards (exchange of rewards for compliance) and management by exception (either actively or passively) [27, 36]; they emphasise legitimate power and respect for rules and tradition [46]. In view of the practices associated with transactional leadership, some authors have connected this leadership style with management functions $[42,43,47,48]$. In contrast, transformational leadership motivates and inspires follower stories above their personal interest for the sake of the organisation; it empowers employees to participate in the process of transforming the organisation and initiate major changes and reforms $[27,34]$. One important outcome of transformational leadership is 'empowerment', which entails sharing of leadership process between the leader and the followers [34, 42]. This feature is consistent with the original idea of Burns that leadership may be exhibited by anyone in the organisation in any type of position [42].
Closely related to the notion of 'shared leadership' is a concept known as 'distributed leader- ship'. As stated earlier, distributed leadership focuses on how actors engage in tasks that are 'stretched' or distributed across the organisation [35]; it sees leadership activities as a situated and social process at the intersection of leaders, followers, and the situation [49]. In practice, leaders from both health management and clinical backgrounds are expected to demonstrate leadership theories as they (the theories) underlie the basis of the knowledge, skills, and attitudes (that is competencies, see below) required by the health management and leadership workforces for successful performance in roles.

\section{Health management and leadership competencies}

The terms 'competency' and 'competence' are often used interchangeably and inconsistently in health management and leadership literature. However, both terms are distinct concepts. Competency refers to the knowledge, skills, and attitudes which health leaders require for effective performance in roles $[\mathbf{1 0}, \mathbf{5 0}, \mathbf{5 1}]$, and can be improved with training and development interventions [51]. Knowledge has been described as a demonstration of the awareness or understanding of the concepts, 
theories, guidelines, or principles required to successfully perform a task [52-54]. Skill, on the other hand, refers to the possession of the capacity to successfully carryout physical or cognitive tasks to achieve a specific outcome [54], while an attitude refers to "a relatively enduring organisation of beliefs, feelings, and behavioural tendencies toward socially significant objects, groups, events or symbols" ([55]p.150). Certain competencies a reconsidered as crucial for successful performance of organisations; such compotencies are known as 'core competencies', a concept first advocated by Prahalad and Hamel [56]. Core competencies have also been described as common competencies which overlap and complement one another and are shared by health managers in a wide range of positions and settings [5]. Although the concept of core competencies engenders understanding and collaboration among individuals, it has been criticised for not taking into consideration the specific needs of each manager in line with his or her dominant management or leadership role [5]. Thus, in addition to identifying core competencies, it may also be useful to identify specific competencies required by certain individuals or members of a professional body for effective performance [5].
Competence is the ability to consistently produce the outcomes (of behaviour) required for effective achievement of organisational goals [57]. In other words, a competent health man- ager or leader possesses the requisite knowledge, skills and attitudes that enable him or her to manage or lead effectively. The term 'proficiency', or 'competence level', refers to the level of expertise for a particular competency. A 'competency model' is a framework which contains competency statements in which essential knowledge, skills and attitudes desirable for specific roles are described [57], or a collection of competencies required for successful performance [58]. A 'competence model', on the other hand, refers to a framework which describes the process and work outputs required to achieve the set goals of specific roles [57].

Other terms commonly associated with competency are 'capability' and 'capacity'. Capability refers to the process which allows individuals to demonstrate or express the required competencies on their jobs; it is the ease with which the required competencies can be accessed, deployed, or applied by individuals [59]. Capacity, on the other hand, refers to the power or ability of individuals to hold or possess the required competencies at a level considered sufficient for a role [59]. 
As pointed out earlier, several studies have been conducted on health management and leadership. The majority of these focused on identification and/ or assessment of essential competencies required by health managers and leaders for effective performance in management and leadership roles. The focus on competencies has been informed by the need to develop strong and competent health management and leadership workforces, given the pivotal roles of leaders from health management and clinical backgrounds in driving changes and leading development in health care organisations. This much has also been recognised by the World Health Organisation, which has advocated the need to strengthen management and leader- ship capabilities at all levels of the health system $[60,61]$. Different approaches are being used to identify and assess essential competencies required by health management and leadership workforces. These approaches include literature review, position description analysis, the Delphi technique, surveys, interview of job incumbents and focus groups. The optimal approach recommended for identification and assessment of competencies involves the use of multiple methods to improve the credibility of findings [54, 62].

A major point of contention in health management and leadership is whether competencies are similar across countries and organisational contexts, or are contextually sensitive. While some authors have argued that certain 'core' competencies are applicable to most health contexts $[5,11]$, others have advocated for more contextually compatible competencies based on the premise that competencies may be influenced by contextual factors such as demographic characteristics of personnel, as well as the size, culture and needs of organisations [12, 22, 63, 64]. Notwithstanding the argument, certain domains of competencies have been identified across several studies as important for health management and leadership roles, regardless of the contexts in which those roles are performed. These domains include communication, interpersonal relationships, business skills, knowledge of the health care environment, professionalism, and leadership $[5,10,11,65]$. A close look at these domains of competencies shows that some, including communication, interpersonal relationships, professionalism and leadership, are people and relationship centred. This is not surprising, given the fact that health care organisations are comprised of human systems where people of diverse backgrounds interact with one another for successful management of the health care 
system [66], and provision of safe, effective and high-quality patient care $[67,68]$.

Although certain competencies may be common to most health contexts, in practice theyare likely to be demonstrated differently, depending on certain factors such as management levels and sectors $[5, \mathbf{1 1}, \mathbf{1 4}$, 21]. In other words, while some competencies maybe similar across most health contexts, the competence level (proficiency) required to demonstrate them will vary from one management level or organisational setting to another. Thus, in addition to identifying the essential competencies required by health management and leadership workforces generally, the health care sector should also focus on the competencies required by specific groups and organisations.

\section{Leadership development in the health caresector}

One of the main goals of competency identification and assessment in health care organisations is to facilitate the development of competency or competence frameworks which are applicable to specific organisations or groups of individuals. Competence-based systems serve as useful means of identifying gaps in proficiency to inform appropriate training, education, or professional development to improve individual competence and organisational performance [69]. The basis for the use of training and professional development to improve health management and leadership competence is found in the evidence that human behaviour can be developed in adulthood [70], and that individuals can change their behaviour, moods and self-images through training [71] and education [72].

The importance of improving the competence in health leadership in both management and clinical workforces has been widely emphasised $[10,11,22,39,60,61,73]$. In the health care sector, approaches and priorities may differ for health management and clinical leadership development. In the light of this, different training and professional development strategies are currently being used to address identified gaps in proficiencies, develop new competencies and improve existing ones. Such strategies include formal training and professional development in the form of structured academic programmes [74], and informal training approaches such as coaching, mentoring, role modelling, workbased or contextual learning and experiential learning $[\mathbf{7 4}, \mathbf{7 5}]$. Both training approaches have been recognised as important in strengthening the capabilities of the management and leadership workforce [75, 
76], especially in complex systems like health [74]. In health care organisations, competency-based training or professional development can be directed at improving the capabilities of individual managers or leaders for effective performance in roles, a concept known as 'leader development' [77]. On the otherhand, such training or professional development interventions can be targeted at strengthening the collective capabilities of the entire management and leadership workforce to achieve 'leadership development' [78]. A more common approach, however, is to focus training and professional development on expanding the capacity of individual managers and leaders to be effective in management or leadership roles [77].

Notwithstanding the crucial place of training and professional development in health management and leadership, evidence of the impact of such development interventions on competence and performance is limited and contentious. While some authors have stated that the evidence linking competency-based training to improved competence and performance remains inconclusive [71-78], others have posited that a positive relationship exists between training and improvement in competence and performance outcomes [22, 72]. Thus, in addition to identifying requisite competencies and corresponding training or professional development opportunities, health care organisations and researchers should put in place appropriate mechanisms to assess the effects of such development interventions on individual competence and, mediated by competent leadership, organisational performance.

Although the competency-based approach has much to offer related to development of leadership capabilities, it has, however, been criticised for focusing mainly on developing specific behaviours considered as essential for successful performance in roles, while ignoring the internal processes which underlie those behaviours [73]. Such internal processes include emotions, mindsets and personal life experiences which significantly impact the behaviours exhibited by leaders [73]. Thus, an approach to leadership development, which focuses on leaders as complete individuals (as against the current practice of concentrating on specific behaviours), has been advocated to ensure holistic leadership development [75]. This model of leadership development is worth exploring in health care organisations.

\section{CONCLUSIONS}

The health care sector is complex, characterised by constant changes and 
reforms. Strong and competent management and leadership workforces are thus required to navigate the sector through the complex web of interacting factors and lead reforms for effective and efficient health care delivery. An added challenge to leadership development is that leadership is spread across health management and clinical workforces; while some clinical leaders may work in management roles, for others leadership is exercised from a clinical position. The need for competent management and leadership workforces has fuelled an upsurge in interest in health management and leadership, as reflected in the large number of studies examining the concept across different countries since the turn of the century. A notable trend in health management and leadership literature is the increasing focus on identification and assessment of essential competencies required by leaders from both health management and clinical backgrounds for effective performance in leadership roles. The purpose of competency identification and assessment in most cases is to inform the development of competency frameworks which are used to assess performance, identify gaps in proficiency and target appropriate training and development opportunities. However, evidence for the impacts of such training or development interventions on the competence of health managers and leaders is currently limited and contentious. Thus, further research is needed to build the evidence on the relationships between targeted training and professional development interventions, individual competence of leaders from health management and clinical backgrounds and organisational performance.

\section{REFERENCES}

[1] Counte MA, Newman JF. Competencybased health services management education: Contemporary issues and emerging challenges. The Journal of Health Administration Education. 2002; 20(2): 113-122

[2] Garman A, Scribner L. Leading for quality in healthcare: Development and validation of a competency model. Journal of Healthcare Management.2011; 56(6): 373

[3] Liang Z, Howard PF. Competencies required by senior health executives in new South Wales, 1990-1999. Australian Health Review. 2010; 34(1): $52-58$

[4] Liang Z, Short SD, Brown CR. Senior health managers in the new era: Changing roles and competencies in the 1990 s and early $21^{\text {st }}$ century. The Journal of Health Administration Education.2006; 23(3): 281-301 
[5] Stefl M. Common competencies for all healthcare managers: The healthcare leadership alliance model. Journal of Healthcare Management.2008; 53(6): 360

[6] Wallick WG, Stager KJ. Healthcare managers' roles, competencies, and outputs in organizational performance improvement/ practitioner response. Journal of Healthcare Management. 2002; 47(6): 390

[7] Leggat SG. Teaching and learning teamwork: Competency requirements for healthcare managers. The Journal of Health Administration Education. 2007; 24(2): 135-149

[8] Guo KL, Anderson D. The new healthcare paradigm: Roles and competencies of leaders in the service line management approach. Leadership in Health Services. 2005; 18(4): 12-20

[9] Gertner EJ, Sabino JN, Mahady E, Deitrick LM, Patton JR, Grim MK, et al. Developing a culturally competent health network: A planning framework and guide/practitioner application. Journal of Healthcare Management. 2010; 55(3): 190

[10] Liang Z, Leggat SG, Howard PF, Koh L. What makes a hospital manager competent at the middle and senior levels? Australian Health Review. 2013a; 37(5): 566-573

[11] Liang Z, Howard PF, Koh LC, Leggat
S. Competency requirements for middle and senior managers in community health services. Australian Journal of Primary Health. 2013b; 19(3): 256-263

[12] Lockhart W, Backman A. Healthcare management competencies: Identifying the GAPs.

Health Management Forum. 2009; 22(2): 30-37

[13] MacKinnon NJ, Chow C, Kennedy PL, Persaud DD, Metge CJ, Sketris I. Management competencies for Canadian health executives: Views from the field. Health Management Forum. 2004; 17(4): 15-20

[14] McCarthy G, Fitzpatrick JJ. Development of a competency framework for nurse managers in Ireland. The Journal of Continuing Education in Nursing. 2009; 40(8): 346350.

[15] Díaz-Monsalve SJ. The impact of health-management training programs in Latin America on job performance. Cadernos de SaúdePública. 2004; 20(4): 1110-1120.

[16] North N, Park E. Potential for a webbased tool to confirm and update health management and leadership competencies. Experiences of a pilot survey in New Zealand. 2012. Asia Pacific Journal of Health Management. 2014; 9(2): 13

[17] Pillay R. Defining competencies for 
hospital management: A comparative analysis of the public and private sectors. Leadership in Health Services. 2008; 21(2): 99-110.

[18] Pillay R. The skills gap in hospital management: A comparative analysis of hospital managers in the public and private sectors in South Africa. Health Services Management Research. 2010; 23(1): 30-36.

[19] Pillay R. The skills gap in nursing management in the South African public health sector. Public Health Nursing. 2011; 28(2): 176-185.

[20] Calhoun JG, Dollett L, Sinioris ME, Wainio JA, Butler PW, Griffith JR, et al. Development of an inter professional competency model for healthcare leadership. Journal of Healthcare Management. 2008; 53(6): 375.

[21] Landry AY, Stowe M, Haefner J. Competency assessment and development among health-care leaders: Results of a cross-sectional survey. Health Services Management Research. 2012; 25(2): 78-86

[22] Reischl TM, Buss AN. Responsive evaluation of competency-based public health preparedness training programs. Journal of Public Health Management and Practice. 2005; 11(6): S100-S105

[23] Hintea C, Cristina M, Țiclau $T$. Leadership and management in the health care system: Leadership perception in Cluj County children's hospital. Transylvanian Review of Administrative Sciences. 2009; 5(27): 89-104.

[24] Dorros GL. Building Management Capacity to Rapidly Scale up Health Services and Health Outcomes. Geneva: World Health Organization; 2006.

[25] Taylor FW. The Principles of Scientific Management. New York: Norton; 1911.

[26] Burns L, Bradley E, Weiner B. Shortel land Kaluzny's Healthcare Management: Organization Design and Behavior. $6^{\text {th }}$ ed. New York: Cengage Learning; 2012.

[27] Creswell JW. Research Design: Qualitative, Quantitative, and Mixed Methods Approaches. Thousand Oaks: Sage Publications; 2009.

[28] Conger JA. Learning to Lead. San Francisco: Jossey-Bass; 1992.

[29] Donelly J, Ivancevich J, Gibson J. Organizations: Behavior, Structure, Processes. $5^{\text {th }}$ ed.

Plano, TX: Business Publications, Inc; 1985.

[30] Northouse PG. Leadership: Theory and Practice. 6th ed. Thousand Oaks: Sage Publications; 2012.

[31] Bennis W, Nanus B. Leaders: The Strategies for Taking Charge. New York: Harper \& Row; 1985. 
[32] Jennings BM, Scalzi CC, Rodgers JD, Keane A. Differentiating nursing leadership and management competencies. Nursing Outlook. 2007; 55(4): 169-175e4.

[33] Daly J, Jackson D, Mannix J, Davidson P, Hutchinson M. The importance of clinical leadership in the hospital setting. Journal of Healthcare Leadership. 2014; 6: 75-83.

[34] Ham C. Improving the performance of health services: The role of clinical leadership. The Lancet. 2003; 361(9373): 1978.

[35] Berwick DM, Enthoven A, Bunker JP. Quality management in the NHS: The doctor's role--II. British Medical Journal.1992; 304 (6822): 304-308.

[36] Bass BM. Handbook of Leadership: Theory, Research, and Managerial Applications. New York: The Free Press; 1990.

[37] Yukl G. Managerial leadership: A review of theory and research. Journal of Management. 1989; 15(2): 251-289.

[38] Rost JC. Leadership for the TwentyFirst Century. Westport, Connecticut: Praeger; 1991.

[39] Pierce JL, Newstrom JW. Leaders \& the Leadership Process: Readings, Selfassessments. Boston: McGraw-Hill Higher Education; 1995.

[40] Smirich L, Morgan G. Leadership: The management of meaning. In: Pierce J, Newstrom J, editors. Leaders \& the Leadership Process: Readings, Selfassessments \& Applications. Boston: McGraw-Hill Higher Education; 1982. p. 17-21.

[41] Yukl G. Leadership in Organizations. New York: Prentice Hall; 1981.

[42] Quinn RE. Beyond Rational Management: Mastering the Paradoxes and Competing Demands of High Performance. San Francisco: JosseyBass; 1988.

[43] Jones G, George J, Hill CWL. Contemporary Management. NewYork: McGraw-Hill; 2000.

[44] Benson AM, Blackman D. To distribute leadership or not? A lesson from the islands. Tourism Management. 2011; 32(5): 1141-1149.

[45] Lucia AD, Lepsinger R. Art \& Science of Competency Models. San Francisco: Jossey-Bass; 1999.

[46] Shewchuk RM, O'Connor S, Fine D. Building an understanding of the competencies needed for health administration practice. Journal of Healthcare Management. 2005; 50(1): 32-34.

[47] Harris MG, Bleakley M. Competencies required of health service managers in the 1990s. Australian Health Review. 1991; 14(4): 363-379

[48] Santric-Milicevic MM, Bjegovic- 
Mikanovic VM, Terzic-Supic ZJ, Vasic

V. Competencies gap of management teams in primary health care. European Journal of Public Health. 2011; 21(2): 247-253.

[49] Marrelli AF, Tondora J, Hoge MA. Strategies for developing competency models. Administration and Policy in Mental Health and Mental Health Services Research. 2005; 32(5): 533561

[50] Hogg MA, Vaughan GM. Social psychology. $4^{\text {th }}$ ed. London: PrenticeHall; 2005

[51] Prahalad C, Hamel G. The core competence of the corporation. Havard Business Review. 1990; 68(3): 79-91.

[52] Teodorescu T. Competence versus competency: What is the difference? Performance Improvement. 2006; 45(10): 27-30.

[53] Garman AN, Johnson MP. Leadership competencies: An introduction. Journal of Healthcare Management. 2006; 51(1): 13 .

[54] Vincent L. Differentiating competence, capability and capacity. Innovating Perspectives. 2008; 16(3): 1-2.

[55] World Health Organization. Towards Better Leadership and Management in Health: Reportonan International Consultationon Strengthening Leadership and Management in LowIncome Countries, Making Health
Systems Work: Working Paper no 10. Geneva:

World Health Organization; 2007.

[56] Egger D, Ollier E. Managing the Health Millennium Development Goals: The Challenge of Management Strengthening: Lessons from three Countries. Geneva, Switzerland: World Health Organization; 2007.

[57] Shippmann JS, Ash RA, Batjtsta M, Carr L, Eyde LD, Hesketh B, et al. The practice of competency modeling. Personnel Psychology. 2000; 53(3): 703-740.

[58] Griffith JR, Warden GL, Neighbors K, Shim B. A new approach to assessing skill needs of senior managers. Journal of Health Administration Education. 2002; 20(1): 75-98.

[59] O'Leary J. Comparison of self-assessed competence and experience among critical care nurses. Journal of Nursing Management.2012; 20(5): 607-614.

[60] Chase LK. Nurse Manager Competencies [Thesis]. Iowa City: University of Iowa; 2010.

[61] Couper I, Hugo J. Management of district hospitals-exploring success. Rural and Remote Health. 2005; 5(4): 433.

[62] Weller J, Boyd M, Cumin D. Teams, tribes and patient safety: Overcoming barriers to effective teamwork in healthcare. Postgraduate Medical 
Journal. 2014; 90 (1061): 149-154

[63] Babiker A, El Husseini M, Al Nemri A, Al Frayh A, Al Juryyan N, Faki MO, et al. Health care professional development: Working as a team to improve patient care. Sudanese Journal of Paediatrics. 2014; 14(2): 9.

[64] Calhoun JG, Davidson PL, Sinioris ME, Vincent ET, Griffith JR. Toward an understanding of competency identification and assessment in health care management. Quality Management in Healthcare. 2002; 11(1): 14.

[65] Boyatzis RE. Competencies in the $21^{\text {st }}$ century. The Journal of Management Development. 2008; 27(1): 5-12.

[66] Morrow CC, Jarrett MQ, Rupinski MT. An investigation of the effect and economic utility of corporate-wide training. Personnel Psychology. 1997; 50(1): 91-117.

[67] Pascarella ET, Terenzini PT. How College Affects Students: Findings and Insights from Twenty Years of Research. San Francisco: JosseyBass; 1991

[68] Blanchard CP, Carpenter B. Experiences of action learning groups for public health sector managers in rural KwaZulu-Natal, South Africa. Rural Remote Health. 2012; 12(3): 111.

[69] Briggs D, Smyth A, Anderson J. In search of capable health managers:
What is distinctive about health management and why does it matter? Asia Pacific Journal of Health Management. 2012; 7(2): 71.

[70] Eraut M. Learning contexts. Learning in Health and Social Care. 2006; 5(1): 1-8.

[71] Uhl-Bien M, Marion R, McKelvey B. Complexity leadership theory: Shifting leadership from the industrial age to the knowledge era. The Leadership Quarterly. 2007; 18(4): 298-318.

[72] Day DV, Dragoni L. Leadership development: An outcome-oriented review based on time and levels of analyses. Annual Review of Organizational Psychology and Organizational Behavior. 2015; 2(1): 133-156.

[73] McCauley C, Van Velsor E, Ruderman M. Introduction: Ourview of leadership development. In: van VelsorE, McCauley CD, Ruderman MN, editors. The Center for Creative Leadership Handbook of Leadership Development. San Francisco: Jossey-Bass; 2010. p.126.

[74] Reeves S, Fox A, Hodges BD. The competency movement in the health professions: Ensuring consistent standards or reproducing conventional domains of practice? Advances in Health Sciences Education. 2009; 14(4): 451-453 
[75] Shewchuk RM, O’Connor SJ, Fine DJ. Bridging the gap: Academic and practitioner perspectives to identify early career competencies needed in healthcare management. The Journal of Health Administration Education. 2006; 23(4): 367-392

[76] Turnock BJ. Roadmap for public health workforce preparedness. Journal of Public Health Management and Practice. 2003; 9(6): 471-480.

[77] Bradley EH, Cherlin E, Busch SH, Epstein A, Helf and B, White WD. Adopting a competency-based model: Mapping curricula and assessing student progress. The Journal of Health Administration Education. 2008; 25(1): $37-51$.

[78] Ruderman MN, Clerkin C, Connolly C. Leadership development beyond competencies moving to a holistic approach. Greensboro, North Carolina: Center for Creative Leadership; 2014. 